\title{
RANCANG BANGUN SISTEM INFORMASI PEMBELAJARAN DI SMK NEGERI 1 TEMBUKU BERBASIS WEB
}

\author{
Luh Putu Risma Noviana 1, *, I Nyoman Bagus Suweta Nugraha² , Ni Luh Gede \\ Ambaradewi ${ }^{3}$ \\ 1,2,3 Prodi Teknik Informatika Universitas PGRI Mahadewa Indonesia, Jalan . Seroja No.57, Tonja, Kec. Denpasar Utara, \\ Kota Denpasar, Bali 80235
}

\begin{abstract}
Abstrak
Kemajuan teknologi informasi saat ini dapat memberikan banyak manfaat terutama dibidang pendidikan. Pembangunan sebuah sistem informasi pembelajaran berbasis web adalah salah satu bagian dari pemanfaatan teknologi informasi. Teknologi informasi dapat mengelola data-data dengan cepat dan mudah. Penerapan sistem informasi pembelajaran di sekolah, mempermudahkan sekolah, guru dan siswa dalam melakukan proses interaksi pembelajaran khususnya di SMK Negeri 1 Tembuku. SMK Negeri 1 Tembuku mengalami kesulitan dalam penyimpanan data yang terlalu banyak terutama guru untuk menginput dan melengkapi data-data kurikulum, siswa untuk melihat jadwal, raport, pembayaran SPP dan absensi, bagian keuangan dalam proses penginputan penerimaan pembayaran SPP dan pengeluaran kas untuk kegiatan sekolah masih secara manual. Hal inilah yang melatar belakangi peneliti untuk merancang sebuah Sistem Informasi Pembelajaran di SMK Negeri 1 Tembuku berbasis web. Metode pengembangan sistem waterfall dan bahasa pemrograman PHP (Hypertext Preprocessor) dan basis data MySQL. Metode pengumpulan data yang digunakan adalah wawancara, obervasi dan studi literature. Berdasarkan hasil pengujian, Sistem Informasi Pembelajaran SMK Negeri 1 Tembuku dapat membantu guru, siswa dan bagian keuangan dalam melakukan proses pembelajaran di sekolah dengan menginput absensi siswa, jurnal, nilai, melihat jadwal pembelajaran, nilai raport, pembayaran SPP, rekap pembayaran SPP dan pengeluaran kas sesuai dengan semester yang aktif secara online.
\end{abstract}

Kata Kunci:

Sistem, Informasi dan

Pembelajaran

\begin{abstract}
Informations teknology development in this time could give so benefit especially in educations part. Informations educations system base on web is one of informations teknology. Informations teknology could process the datas fast and easy. Implementations education information system in the school, make easier teacher and student in educations interactions. System process especially in SMK Negeri 1 Tembuku. SMK Negeri 1 Tembuku face the trouble in saving data so many datas especially teacher to input and completed curriculum datas, student to see the schedule, raport, SPP payment and absence. Financial part on process input SPP payment receive and expending of cash to school activities still on manual. This is the observer to make a educations system informations in SMK Negeri 1 Tembuku base on web. Waterfall development method and PHP (Hypertext Processor) programmer and datas MySQL. Data collected method used is interview, observations, and literature study. Base on result, educations informations system in SMK Negeri 1 Tembuku can help the teacher, student and financial part to do educations process in the school by inputting student abcency, jurnal, value, to see the lessons schedule, raport value, DPP payment, app payment recap and expending khas base on onlinely aktif semester.
\end{abstract}

Keywords:

System, Information and Learning 


\section{PENDAHULUAN}

Sistem Informasi adalah sekumpulan hardware, software, brainware, prosedur dan atau aturan yang diorganisasikan secara integral untuk mengolah data menjadi informasi yang bermanfaat guna memecahkan masalah dan pengambilan keputusan. Hampir setiap instansi, seperti instansi pendidikan, instansi kesehatan, dan instansi lainnya memerlukan sistem informasi. Dengan berkembangnya teknologi di zaman sekarang yang semakin maju dan kebutuhan akan informasi dengan penggunaan komputer yang semakin cepat sehingga dapat mendukung dalam dunia pendidikan. Salah satunya memanfaatkan MySQL sebagai penyimpanan database bersifat open source dan sering digunakan dalam pembuatan web.

Sekolah SMK Negeri 1 Tembuku menjadi salah objek penelitian. SMK Negeri 1 Tembuku yang berlokasi Desa Bangbang Kecamatan Tembuku Bangli berdiri pada bulan Juli 2011 atas tokoh-tokoh masyarakat Desa Bangbang bersama Pemerintah Kabupaten Bangli dimana ditetapkan berdasarkan SK Peraturan Bupati Bangli Nomor 26 Tahun 2011 Tentang Penetapan Pendirian Sekolah Menengah Kejuruan (Smk) Negeri 1 Tembuku Kabupaten Bangli (https://peraturan.bpk.go.id). Kemajuan teknologi informasi saat ini dapat memberikan banyak manfaat terutama dibidang pendidikan. Pembangunan sebuah sistem informasi pembelajaran berbasis web adalah salah satu bagian dari pemanfaatan teknologi informasi. Teknologi informasi dapat mengelola data-data dengan cepat dan mudah. Penerapan sistem informasi pembelajaran di sekolah, mempermudahkan sekolah, guru dan siswa dalam melakukan proses interaksi pembelajaran khususnya di SMK Negeri 1 Tembuku. SMK Negeri 1 Tembuku mengalami kesulitan dalam penyimpanan data yang terlalu banyak terutama guru untuk menginput dan melengkapi data-data kurikulum, siswa untuk melihat jadwal, raport, pembayaran SPP dan absensi, bagian keuangan dalam proses penginputan penerimaan pembayaran SPP dan pengeluaran kas untuk kegiatan sekolah masih secara manual. Berdasarkan latar belakang masalah diatas, maka penulis menjadikan "Sistem Informasi Pembelajara di SMK Negeri 1 Tembuku Berbasis Web" sebagai judul penelitian.

\section{METODE}

\section{A. Metode Pengembangan Sistem}

Metode pengembangan sistem yang digunakan dalam penelitian ini adalah metode waterfall. Metode waterfall merupakan model pengembangan sistem informasi yang sistematik dan sekuensial.

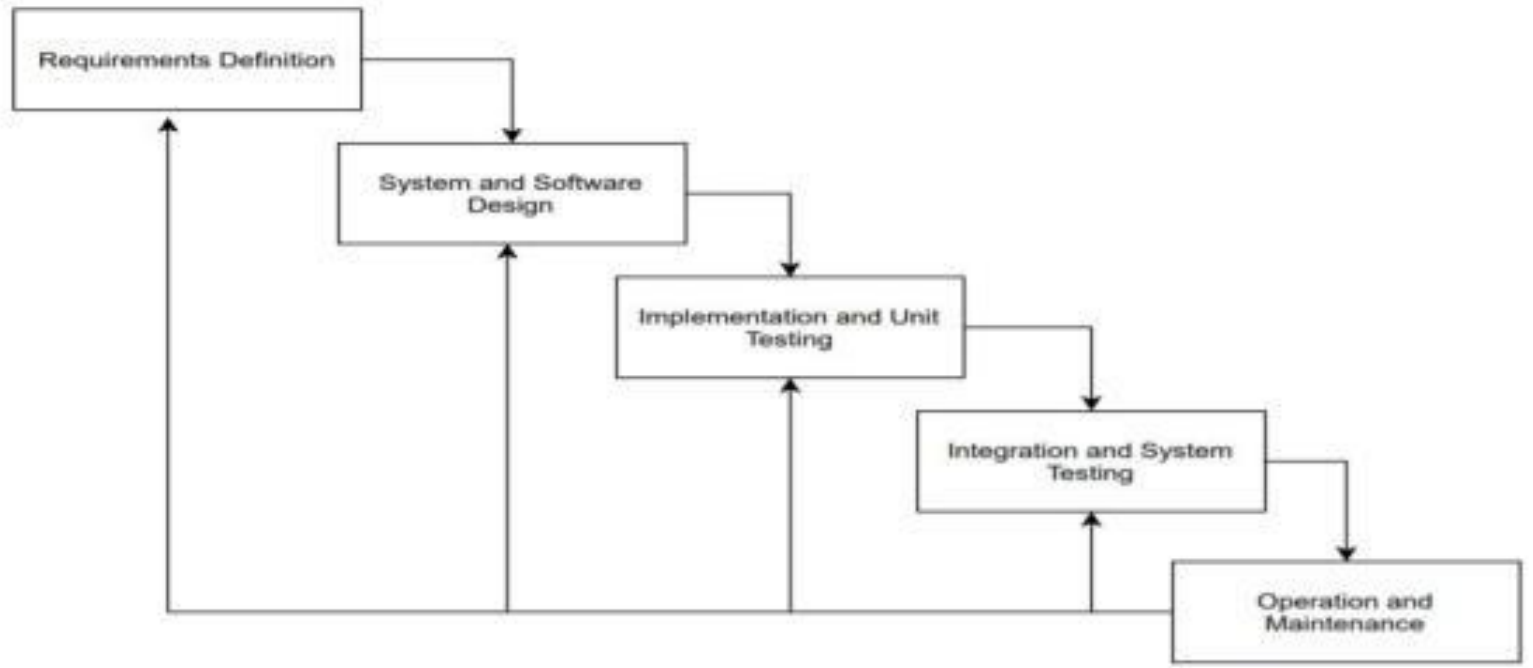

Gambar 1. Metode waterfall

Metode Waterfall memiliki tahapan-tahapan sebagai berikut:

\section{Requirements analysis and definition}

Tahapan ini adalah tahapan perencanaan pada sistem yang akan dikembangkan. Pada tahapan ini penulis melakukan:

a. Pengamantan terhadap sistem pembelajaran pembelajaran yang sedang berjalan di SMK Negeri 1 Tembuku

b. Melakukan identifikasi masalah yang terjadi pada sistem pembelajaran akademik sedang berjalan 
c. Pengumpulan penggunaan user

d. Sistem Informasi Pembelajaran ini sendiri diperuntukkan kepada admin, guru dan siswa sebagai user.

\section{System and software design}

Pada tahap ini menghasilkan rancangan yang memenuhi kebutuhan yang ditentukan selama tahapan analisis sistem.

a. Design Aplikasi

Untuk perancang apliaksi, penulis menggunakan alat bantu sequence diagram untuk menjelaskan alur kerja dari aplikasi.

b. Design Database

Pada tahap perancangan basis data, penulis menggunakan class diagram sebagai tool untuk merancang relasi antar tabel dalam database.

\section{Implementation and unit testing}

Pada tahap implementasi terhadap keseluruhan aplikasi setelah pengkodean (coding) pada setiap modul selesai dilakukan. Pengujian meliputi proses input data-data akademik dan melakukan pengujian untuk memastikan kebenaran dan kesalahan yang muncul karena salah tulis coding.

\section{Integration and system testing}

Unit-unit individu program atau program digabung dan diuji sebagai sebuah sistem lengkap untuk memastikan apakah sesuai dengan kebutuhan perangkat lunak atau tidak.

\section{Operation and maintenance}

Melakukan perbaikan, perubahan atau penambahan program sesuai dengan kebutuhan yang diperlukan dalam sistem informasi pembelajaran di SMK Negeri 1 Tembuku (Sispemkatem)

\section{B. Metode Pengumpulan Data}

Dalam pembuatan dan penyusunan penelitian, ada beberapa metode yang dilakukan untuk mengumpulkan data-data yang nantinya akan dipergunakan yaitu:

1. Wawancara

Metode wawancara yaitu penulis melakukan kegiatan tanya jawab secara langsung dengan guru, siswa di bidang infrastruktur sebagai narasumber

2. Observasi

Penulis melakukan pengamatan di lingkungan Sekolah SMK Negeri 1 Tembuku untuk mendapatkan data-data yang berkaitan dengan sistem informasi pembelajaran

3. Metode Studi Literature

Studi literatur adalah mencari referensi teori yang relevan dengan studi kasus yang diangkat dan permasalahan yang ditemukan.

\section{Perancangan Sistem}

UML (Unified Modeling Language) merupakan salah satu bahasa yang banyak digunakan dalam membuat analisa \& desain, serta menggambarkan arsitektur dalam pemrogram berorintasi objek. Rosa dan Shalahuddin (2014:48). Berikut ini empat diagram yang digunakan dalam merancang sebuah aplikasi yaitu:

1. Use Case Diagram

Use case diagram merupakan salah satu permodelan untuk melakukan sistem informasi yang akan dibuat.

2. Activity Diagram

Activity Diagram merupakan gambaran aliran kerja (work flow) atau activity dari sebuah sistem atu menu yang ada pada sistem yang akan dirancang.

3. Sequence Diagram

Sequence Diagram menggambarkan kelakuan objek pada use case dengan menjelaskan waktu objek dan message yang dikirimkan dan diterima antar objek.

4. Class Diagram

Class Diagram menggambarkan struktur sistem dari segi pendefinisan kelas-kelas yang akan dibuat untuk membangun sistem sehingga kelas memiliki atribut dan metode atau operasi. 


\section{HASIL DAN PEMBAHASAN}

\section{A. Gambar Umum Sistem}

Gambar umum sistem yang akan dikembangkan adalah sebuah sistem informasi berbasis web yang penulis usulkan adalah mengenai sistem informasi pembelajaran di SMK Negeri 1 Tembuku. Adapun gambar umum dari sistem informasi pembelajaran pada Gambar 2.

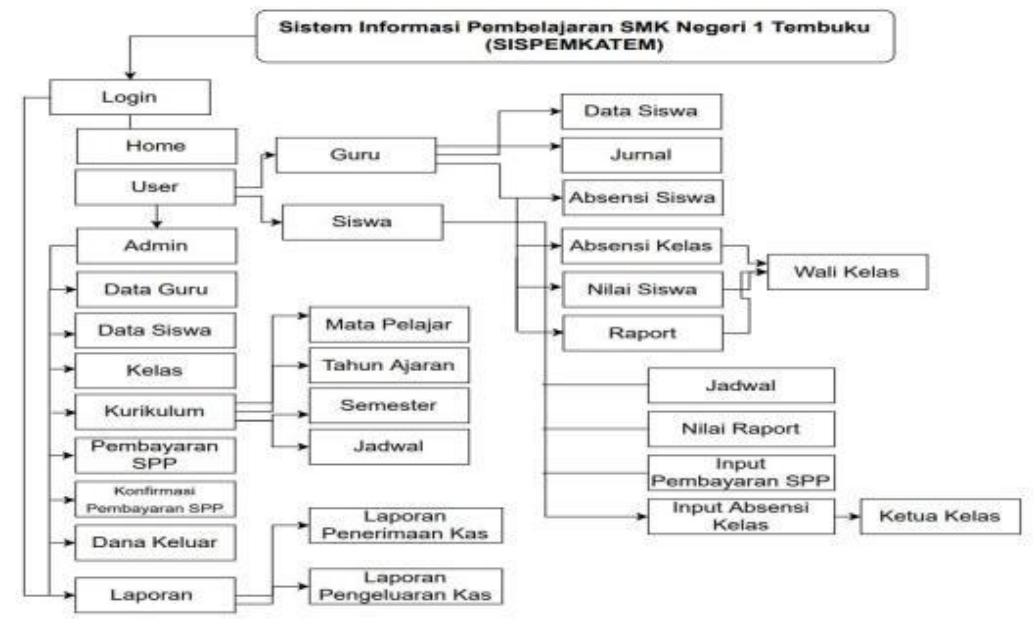

Gambar 2. Gambar umum sistem

\section{B. Perancangan Sistem}

\section{a. Activity Diagram}

Berikut ini merupakan activity diagram dari sispemkatem yang dibuat terdiri dari 5 yaitu activity diagram guru wali kelas, activity diagram guru mata pelajaran, activity diagram ketua kelas, activity diagram siswa, dan activity diagram admin.

\section{b. Activity Diagram Guru Wali Kelas}

Pada Gambar 3 merupakan activity diagram guru wali kelas dimana guru melakukan login ke sistem dan sistem akan mengecek apakah username dan password benar atau salah, Jika benar maka guru wali kelas bisa melihat data siswa, input jurnal, input absensi siswa per mapel, melihat absensi siswa, input nilai dan melihat raport.

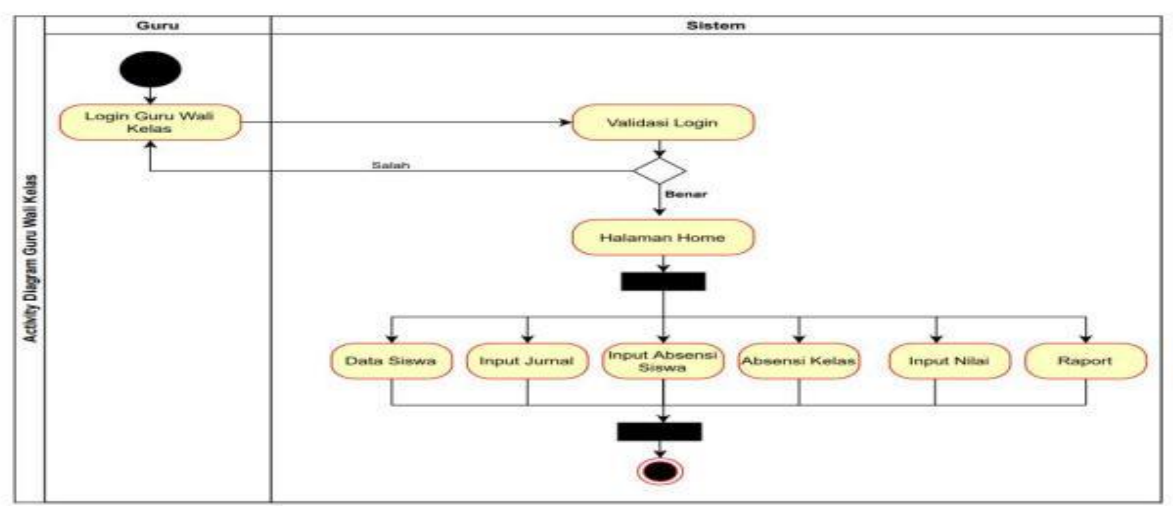

Gambar 3. Activity diagram guru wali kelas

\section{c. Activity Diagram Guru Mata Pelajaran}

Pada Gambar 4 merupakan activity diagram guru mapel dimana guru melakukan login sistem dan sistem akan mengecek apakah username dan password benar atau salah, Jika benar maka guru wali kelas bisa melihat data siswa, input jurnal, input absensi siswa per mata pelajaran 


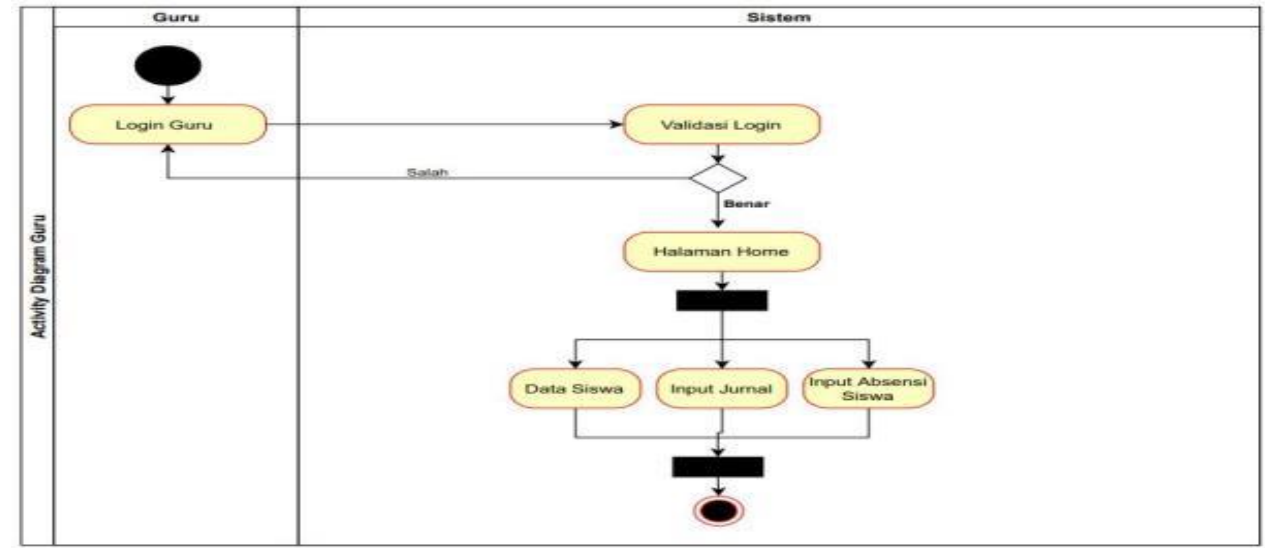

Gambar 4. Activity diagram guru mata pelajaran

\section{Activity Diagram Ketua Kelas}

Pada Gambar 5 merupakan activity diagram ketua kelas dimana ketua kelas melakukan login ke sistem dan sistem akan mengecek apakah username dan password benar atau salah, Jika benar maka ketua kelas bisa melihat jadwal pembelajaran, melihat nilai raport, input pembayaran SPP dan input absensi kelas.

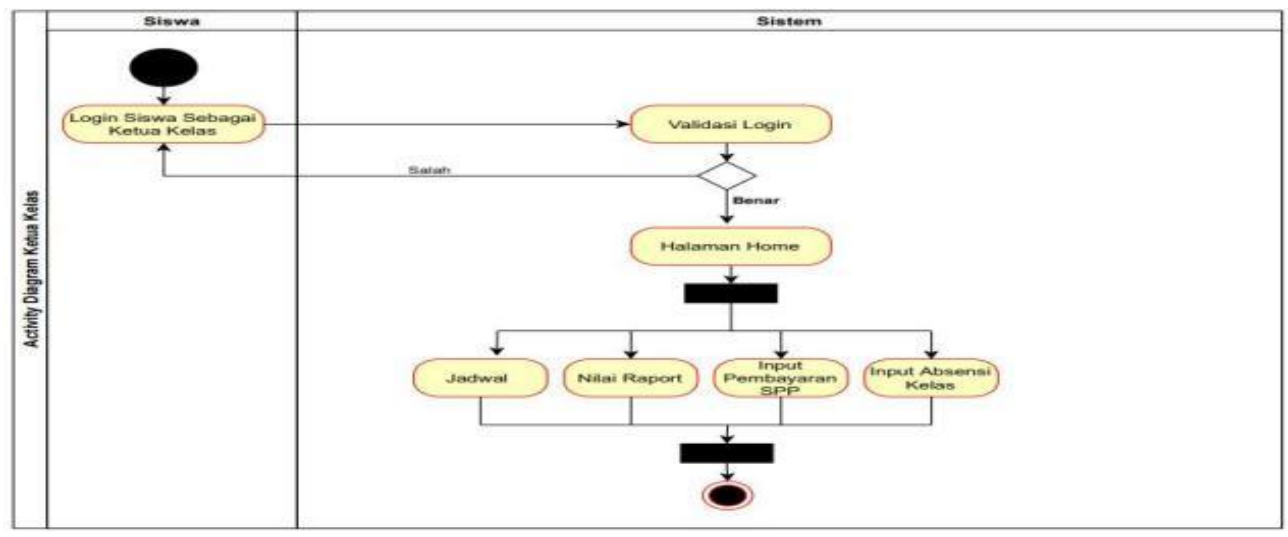

Gambar 5. Activity diagram ketua kelas

\section{Activity Diagram Siswa}

Pada Gambar 6 merupakan activity diagram siswa dimana siswa melakukan login ke sistem dan sistem akan mengecek apakah username dan password benar atau salah, Jika benar maka siswa bisa melihat jadwal pembelajaran, melihat nilai raport dan input pembayaran SPP.

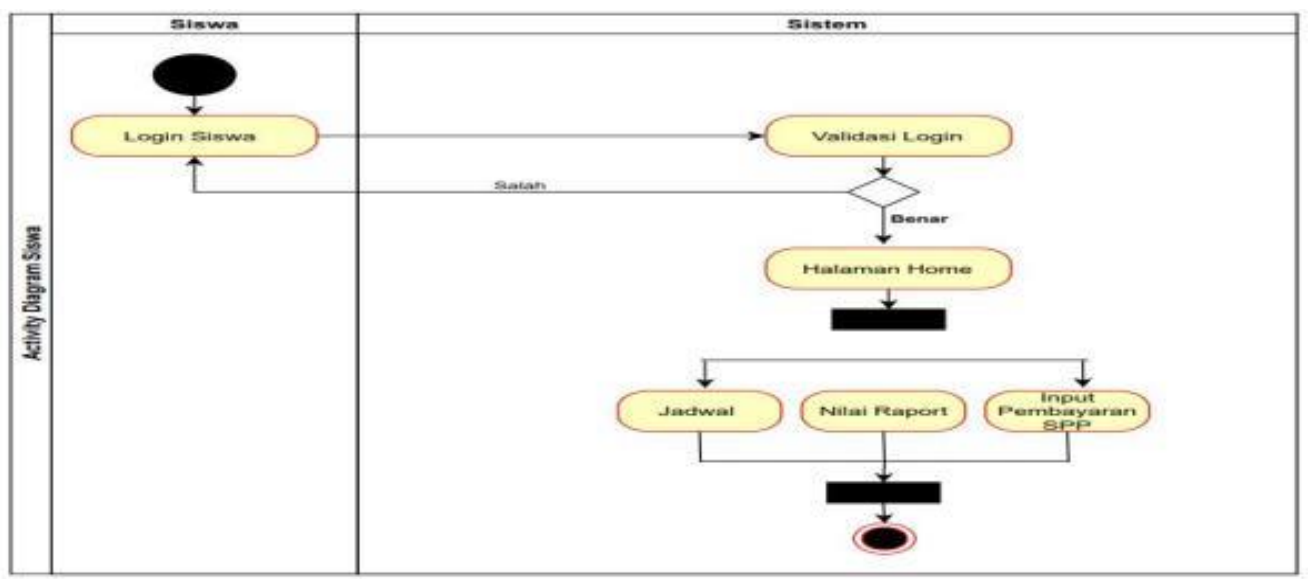

Gambar 6. Activity diagram siswa 


\section{Activity Diagram Admin}

Pada Gambar 7 merupakan activity diagram admin dimana admin melakukan login ke sistem dan sistem akan mengecek apakah username dan password benar atau salah, Jika benar maka admin bisa input data guru, input data siswa, input mata pelajaran, input tahun ajaran, input semester, input jadwal, input kelola kelas, input pembayaran SPP, input dana keluar dan mencetak laporan pembayaran SPP dan dana keluar.

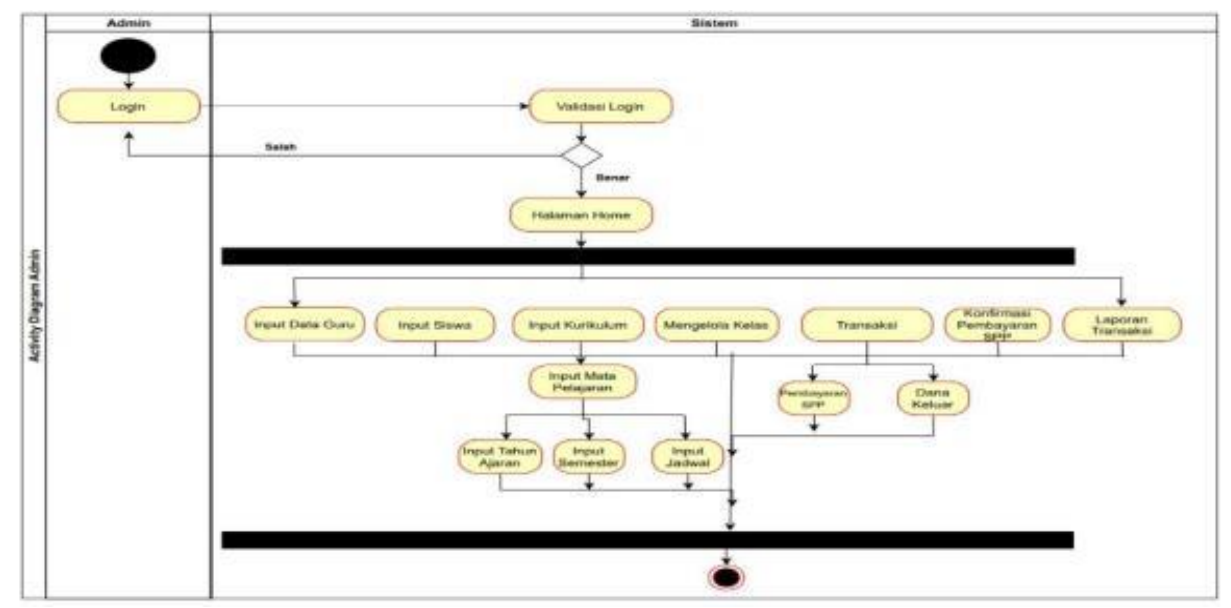

Gambar 7. Activity diagram admin

\section{d. Class Diagram}

\section{Class Diagram Guru}

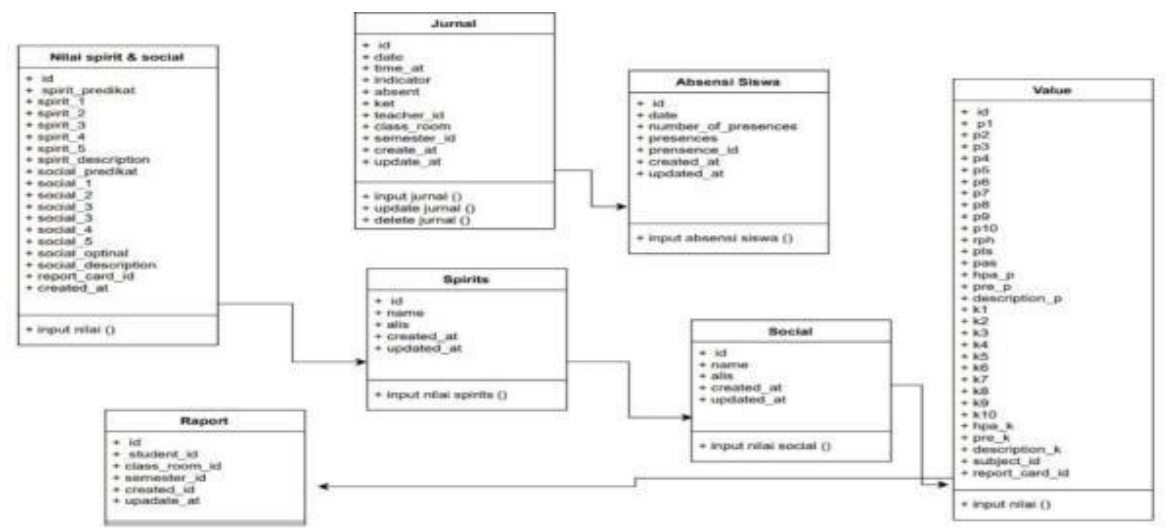

Gambar 8. Class diagram guru

\section{Class Diagram Siswa}

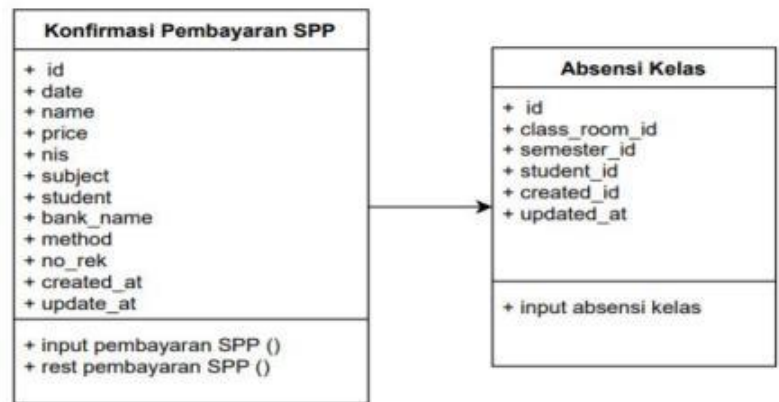

Gambar 9. Class diagram siswa 


\section{Class Diagram Admin}

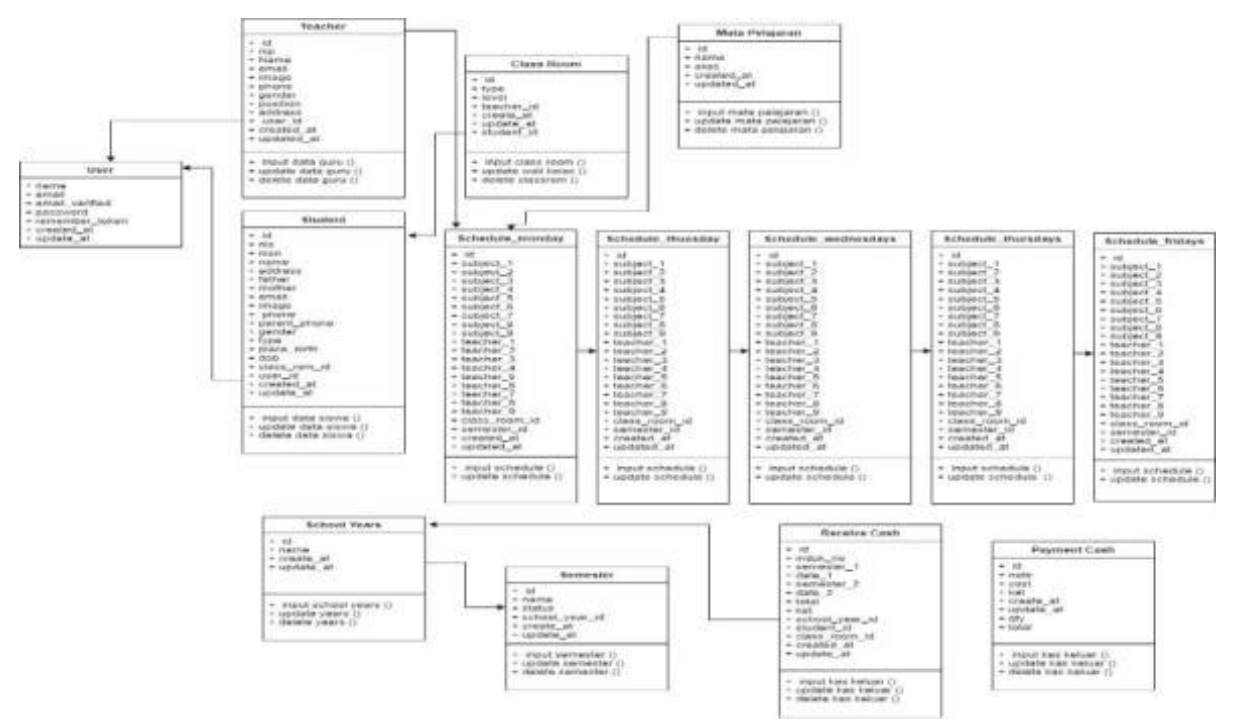

Gambar 10. Class diagram admin

\section{Implementasi}

Berikut ini merupakan hasil implementasi dari Rancang Bangun Sistem Informasi Pembelajaran Di SMK Negeri 1 Tembuku berbasis web dan basis data yang digunakan adalah MySQL dan Laragon. Sistem yang akan dihasilkan secara langsung dengan digunakan untuk proses pembelajaran di kelas. User dalam sistem ini terdiri dari 3 (tiga) yaitu admin, guru terdiri dari guru mata pelajaran dan guru wali kelas, siswa terdiri dari siswa sebagai ketua kelas dan siswa memilik tugas dan fungsi masing-masing. Alur sistem pertama melakukkan login sesuai dengan username seperti pada Gambar 11. Halaman admin dapat melakukan proses input guru, input data siswa, input data kelas, input mata pelajaran, input tahun ajaran, input semester, input jadwal, input pembayaran SPP, input konfirmasi pembayaran SPP dan input dana keluar seperti pada Gambar 12. Halaman guru mata pelajaran dapat melakukan melihat data siswa, input jurnal dan input absensi siswa sesuai dengan mata pelajaran seperti pada Gambar 13. Halaman guru wali kelas dapat melakukan melihat data siswa, input jurnal, melihat absensi kelas yang diinput oleh ketua kelas, input absensi sesuai dengan mata pelajaran, input nilai siswa dan raport seperti pada Gambar 14. Halaman siswa sebagai ketua kelas dapat melakukan melihat jadwal mata pelajaran, melihat nilai raport, input pembayaran SPP, input absensi kelas seperti pada Gambar 15. Siswa terdiri dari melihat jadwal mata pelajaran, melihat nilai raport dan input pembayaran SPP seperti pada Gambar 16.

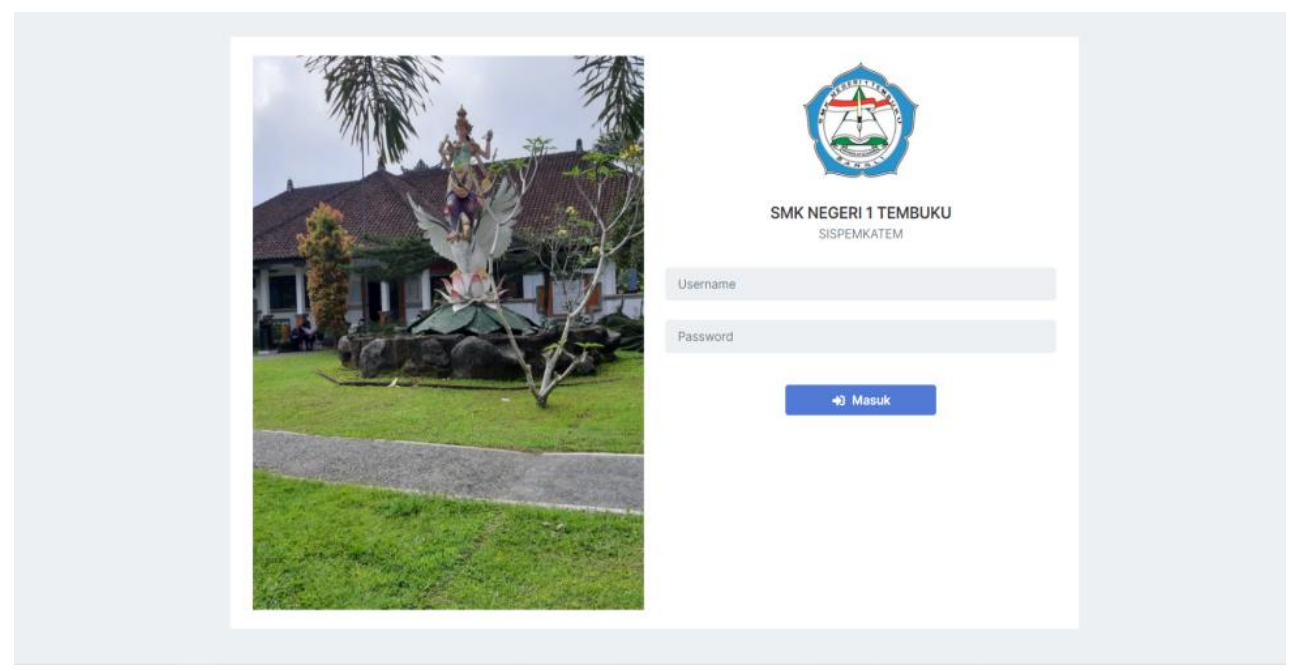

Gambar 11. Halaman login 
66 INSERT: Information System and Emerging Technology Journal. Vol. 2, No. 2, Desember 2021

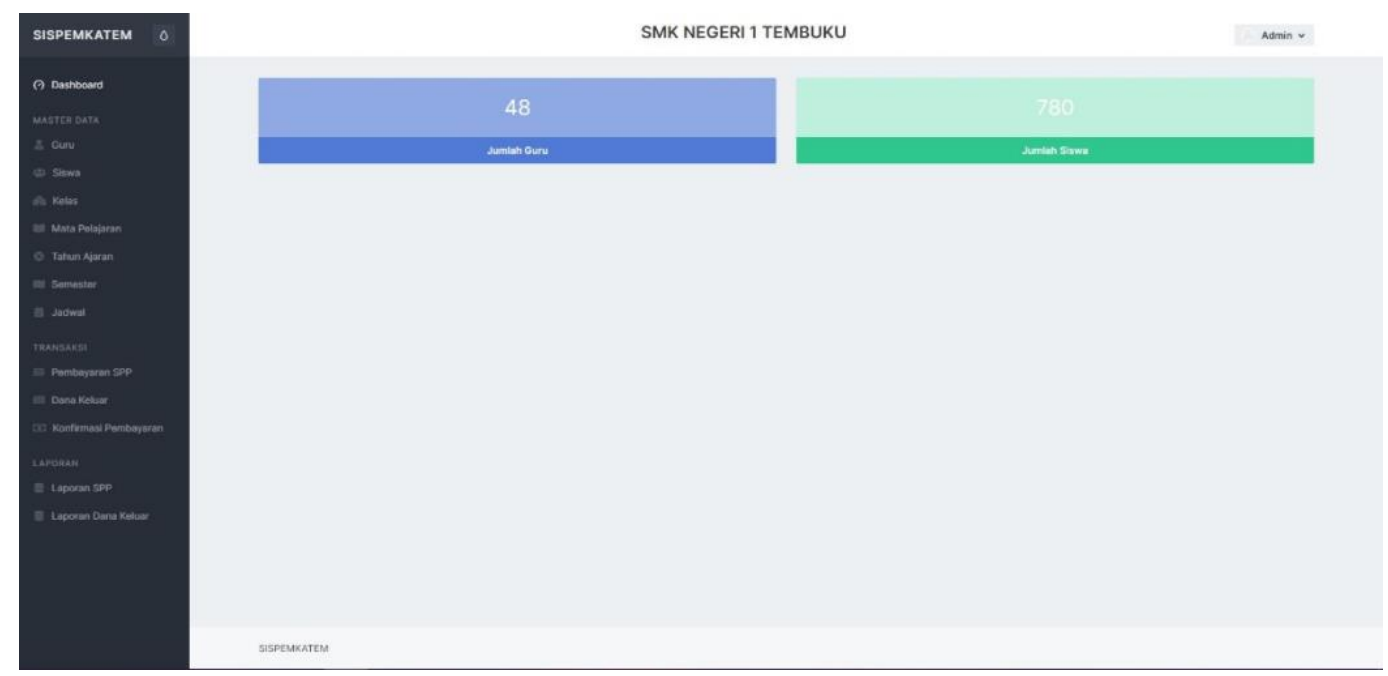

Gambar 12. Halaman admin
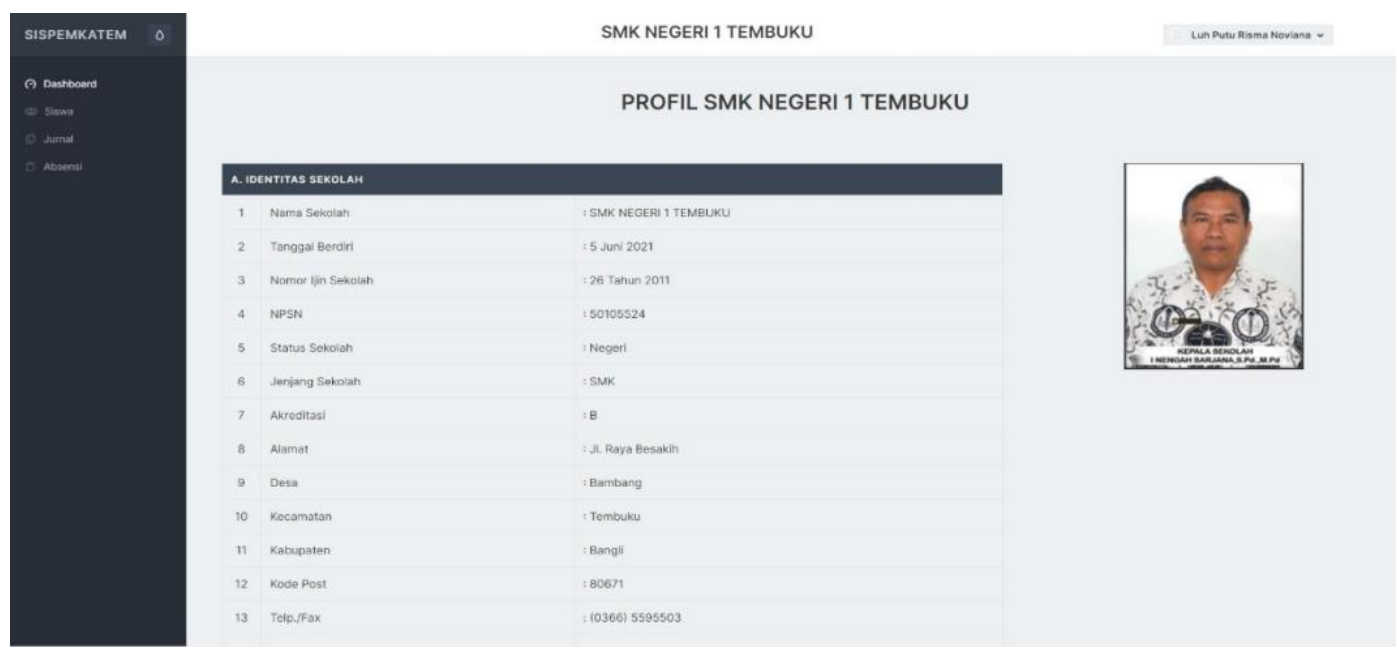

Gambar 13. Halaman guru mata pelajaran

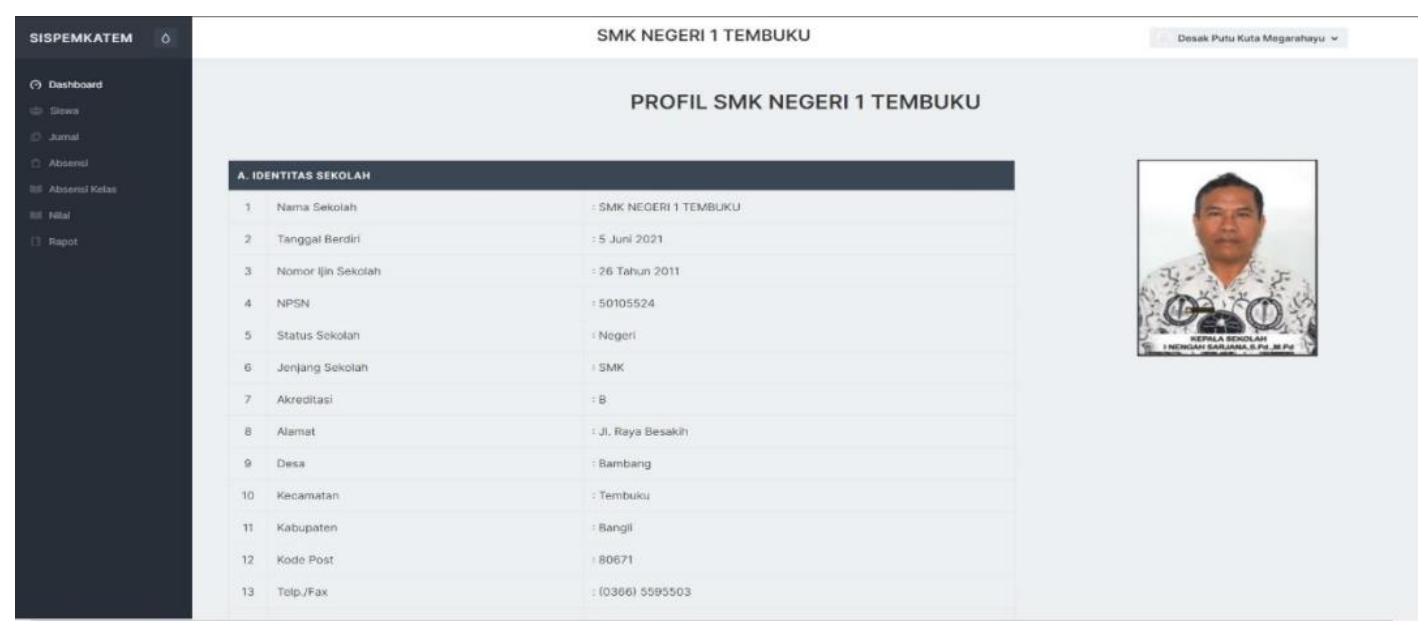

Gambar 14. Halaman guru wali kelas 


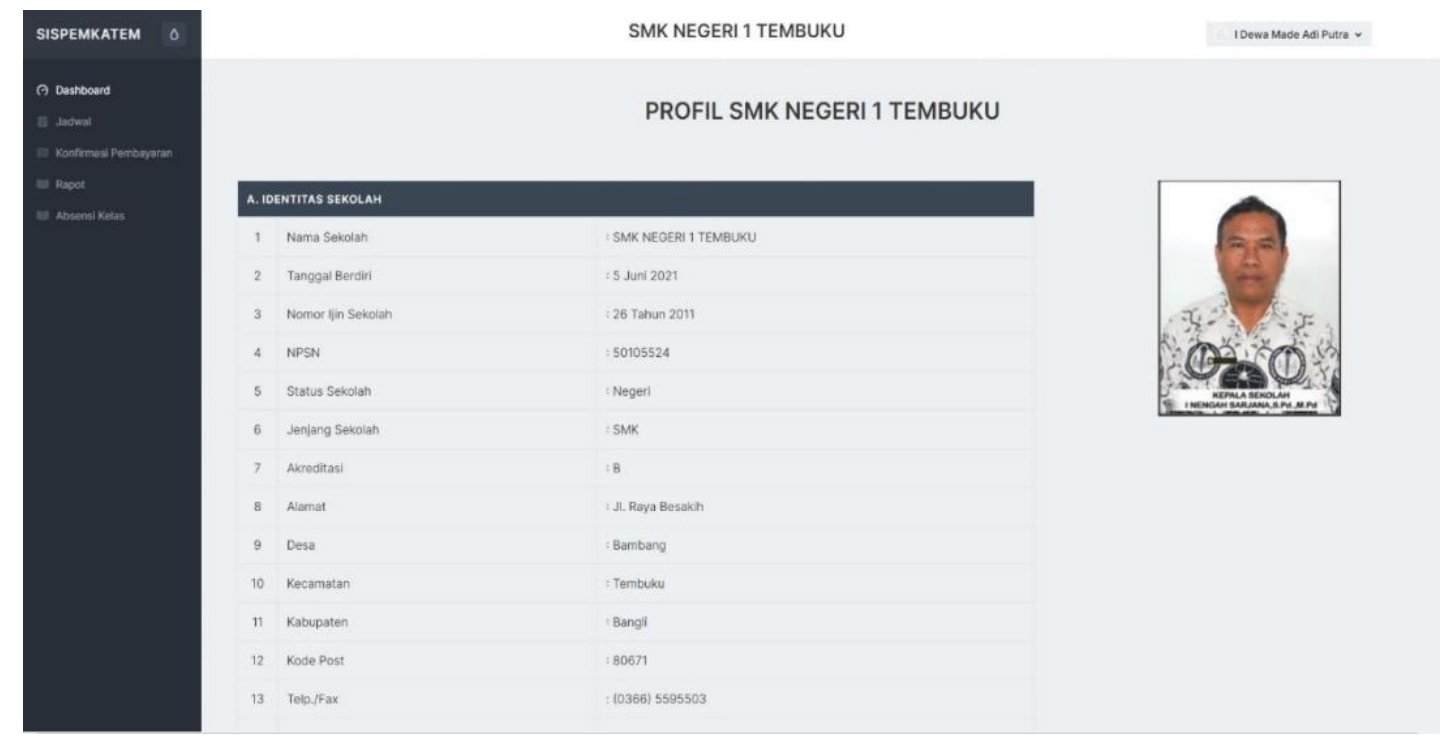

Gambar 15. Halaman ketua kelas

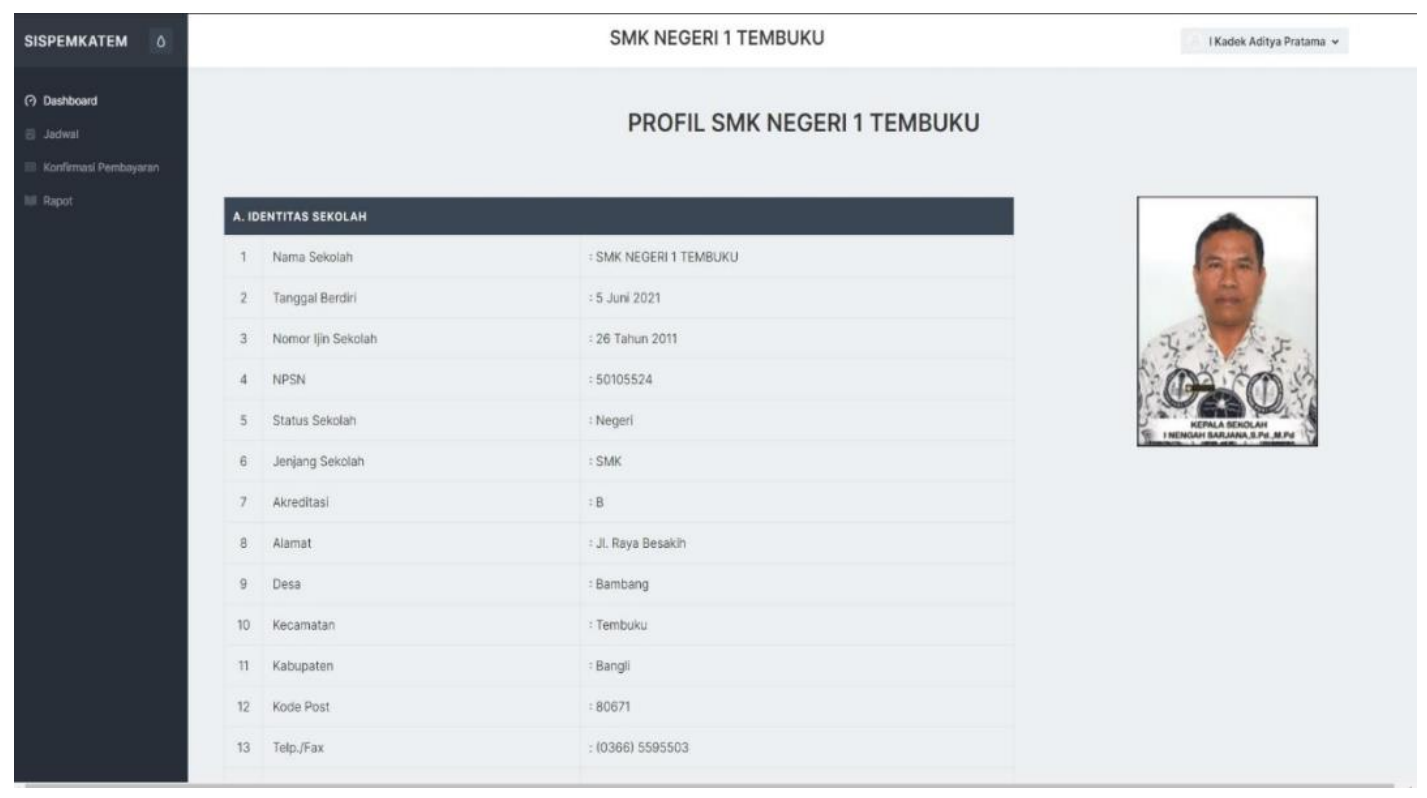

Gambar 16. Halaman kelas

\section{Pembahasan dan Pengujian Sistem}

Metode pengujian sistem menggunakan metode blackbox. Pengujian Sistem Informasi Pemberlajaran Di SMK Negeri 1 Tembuku dalam penelitian ini dilaksanakan oleh pihak user atau pengguna dengan aspek fundamental sistem tanpa memperhatikan struktur logika internal perangkat lunak. Adapun hal-hal yang akan diujikan dalam sistem sebagai berikut:

\section{a. Pengujian Fungsi Login} telah dibuat.

Berikut ini proses yang bertujuan untuk mengetahui keberhasilan fungsi login pada sistem yang 
68 INSERT: Information System and Emerging Technology Journal. Vol. 2, No. 2, Desember 2021

Tabel 1. Pengujian fungsi login

\begin{tabular}{lllll}
\hline No & Input & $\begin{array}{l}\text { Output yang } \\
\text { diharapkan }\end{array}$ & Output sistem & Kesimpulan \\
\hline 1 & $\begin{array}{l}\text { Menginputkan } \\
\text { username dan } \\
\text { password yang valid }\end{array}$ & $\begin{array}{l}\text { Menampilkan } \\
\text { halaman dashboard } \\
\text { dan menutup form } \\
\text { login }\end{array}$ & $\begin{array}{l}\text { Tampil halaman } \\
\text { dashboard }\end{array}$ & Valid \\
2 & $\begin{array}{l}\text { Menginputkan } \\
\text { username dan } \\
\text { password yang valid }\end{array}$ & $\begin{array}{l}\text { Menampilkan tetap } \\
\text { dihalaman login }\end{array}$ & $\begin{array}{l}\text { Sesuai dengan Valid } \\
\text { output yang } \\
\text { diharapkan }\end{array}$ & \\
\hline
\end{tabular}

\section{b. Pengujian Fungsi Tambah Data Jadwal}

Berikut ini proses yang bertujuan untuk mengetahui keberhasilan fungsi tambah data jadwal pada sistem yang telah dibuat.

Tabel 2. Pengujian fungsi tambah data jadwal

\begin{tabular}{llllll}
\hline No & Input & $\begin{array}{l}\text { Output yang } \\
\text { diharapkan }\end{array}$ & Output sistem & Kesimpulan \\
\hline 1 & $\begin{array}{l}\text { Menginputkan } \\
\text { data jadwal } \\
\text { dengan lengkap }\end{array}$ & $\begin{array}{l}\text { Menampilkan berhasil } \\
\text { nambah data jadwal }\end{array}$ & $\begin{array}{l}\text { Tampil } \\
\text { jadwal }\end{array}$ & dihalaman & Valid \\
& $\begin{array}{l}\text { Menginputkan } \\
\text { data jadwal } \\
\text { tidak lengkap }\end{array}$ & Menampilkan pesan & $\begin{array}{l}\text { Tidak } \\
\text { dihalaman jadwal }\end{array}$ & \\
& & & tampil & Valid \\
\hline
\end{tabular}

\section{c. Pengujian Fungsi Input Pembayaran SPP}

Berikut ini proses yang bertujuan untuk mengetahui keberhasilan fungsi input pembayaran SPP pada sistem yang telah dibuat.

Tabel 3. Pengujian fungsi input pembayaran SPP

\begin{tabular}{|c|c|c|c|c|}
\hline No & Input & $\begin{array}{l}\text { Output } \\
\text { diharapkan }\end{array}$ & Output sistem & Kesimpulan \\
\hline 1 & $\begin{array}{lr}\text { Menginputkan } & \text { data } \\
\text { pembayaran } & \text { SPP } \\
\text { lengkap } & \end{array}$ & $\begin{array}{l}\text { Menampilkan berhasil } \\
\text { nambah data } \\
\text { pembayaran SPP }\end{array}$ & $\begin{array}{l}\text { Tampil dihalaman } \\
\text { pembayaran SPP }\end{array}$ & Valid \\
\hline 2 & $\begin{array}{ll}\text { Menginputkan } & \text { data } \\
\text { pembayaran } & \text { SPP } \\
\text { tidak lengkap } & \end{array}$ & $\begin{array}{l}\text { Menampilkan } \\
\text { error }\end{array}$ & $\begin{array}{l}\text { Tidak tampil } \\
\text { dihalaman } \\
\text { pembayaran SPP }\end{array}$ & Valid \\
\hline
\end{tabular}

\section{d. Pengujian Fungsi Input Dana Keluar}

Berikut ini proses yang bertujuan untuk mengetahui keberhasilan fungsi input dana keluar pada sistem yang telah dibuat.

Tabel 4. Pengujian fungsi input dana keluar

\begin{tabular}{lllll}
\hline No & Input & $\begin{array}{l}\text { Output yang } \\
\text { diharapkan }\end{array}$ & Output sistem & Kesimpulan \\
\hline 1 & Menginputkan data dana & Menampilkan & Tampil dihalaman & Valid \\
& keluar lengkap & $\begin{array}{l}\text { berhasil nambah } \\
\text { data dana keluar }\end{array}$ & $\begin{array}{l}\text { dana keluar dan } \\
\text { masuk dilaporan } \\
\text { dana keluar }\end{array}$ & \\
& & & & \\
\hline
\end{tabular}


Tidak tampil Valid

dihalaman dana

keluar dan tidak

masuk dilaporan

dana keluar

\section{SIMPULAN DAN SARAN}

Berdasarkan hasil analisis dan pembahasan dari Sistem Informasi Pembelajaran Di SMK Negeri 1 Tembuku maka dapat disimpulkan sebagai berikut:

1 Perancangan sistem menggunakan usecase, activity diagram, sequence diagram dan class diagram untuk membuat gambar atau alur dari sistem.

2 Basis data yang dirancang memakai tabel sebagai tempat penyimpanan data meggunakan MySQL dan laragon digunakan sebagai server localhost

3 Metode pengembangan sistem yang digunakan metode waterfall

4 Pengujian sistem dengan metode black box testing dengan didapatkan hasil sesuai dengan semua fungsi yang diharapkan

5 Implementasi sistem dengan bantuan google sebagai media untuk menampilkan web dari sistem.

6 Visual studio code digunakan sebagai editor dalam pembuat coding dari sistem

\section{Daftar Pustaka}

Arbani, M. (2011). Pengembangan Sistem Informasi Sekolah Berbasis Web (Studi Kasus : Mi An-Nizhomiyah Depok). Pengembangan Sistem Informasi Sekolah Berbasis WEB, 1, 141.

Destiningrum, M., \& Adrian, Q. J. (2017). Sistem Informasi Penjadwalan Dokter Berbassis Web Dengan Menggunakan Framework Codeigniter (Studi Kasus: Rumah Sakit Yukum Medical Centre). Jurnal Teknoinfo, 11(2), 30. https://doi.org/10.33365/jti.v11i2.24

Dharwiyanti, S., \& Wahono, R. S. (2003). Pengantar Unified Modeling Language (UML). IlmuKomputer.Com, 1-13. http://www.unej.ac.id/pdf/yanti-uml.pdf

Francisco, A. R. L. (2013). Konsep Dasar Sistem. Journal of Chemical Information and Modeling, 53(9), 16891699. https:// repository. bsi.ac.id /index. php/ unduh/item/1726/9.-BAB-II-LANDASAN-TEORI.pdf

Goleman. (2019). Konsep Dasar Sistem. Journal of Chemical Information and Modeling, 53(9), 1689-1699.

Hermiyanty, Wandira Ayu Bertin, D. S. (2017). Pembelajaran Latar. Journal of Chemical Information and Modeling, 8(9), 1-58.

Kadir, A. (2014). Pengertian Sistem Informasi Menurut Abdul Kadir. In Pengenalan Sistem Informasi Edisi Revisi.

Parno, M. (2008). Konsep Dasar Sistem Informasi (Review). Konsep Dasar Sisitem Informasi (Review), 1(1), 1-10. parno.staff.gunadarma.ac.id > SI_01_Konsep_Dasar_SI

Pane, A. (2017). Belajar dan Pembelajaran Aprida Pane Muhammad Darwis Dasopang. Fitrah, 03(2), 333352.

Putra, I. (2005). Perancangan Sistem Informasi Pembelajaran Berbasis Web Pada United Tractors School Palembang, 1-6.

Rosidah;. (2018). Bab Ii Landasan Teori. Journal of Chemical Information and Modeling, 53(9), 8-24.

Santoso, S., \& Nurmalina, R. (2017). Perencanaan dan Pengembangan Aplikasi Absensi Mahasiswa Menggunakan Smart Card Guna Pengembangan Kampus Cerdas (Studi Kasus Politeknik Negeri Tanah Laut). Jurnal Integrasi, 9(1), 84-91.

Sasmito, G. W. (2017). Penerapan Metode Waterfall Pada Desain Sistem Informasi Geografis Industri Kabupaten Tegal. Jurnal Informatika:Jurnal Pengembangan IT (JPIT), 2(1), 6-12. 